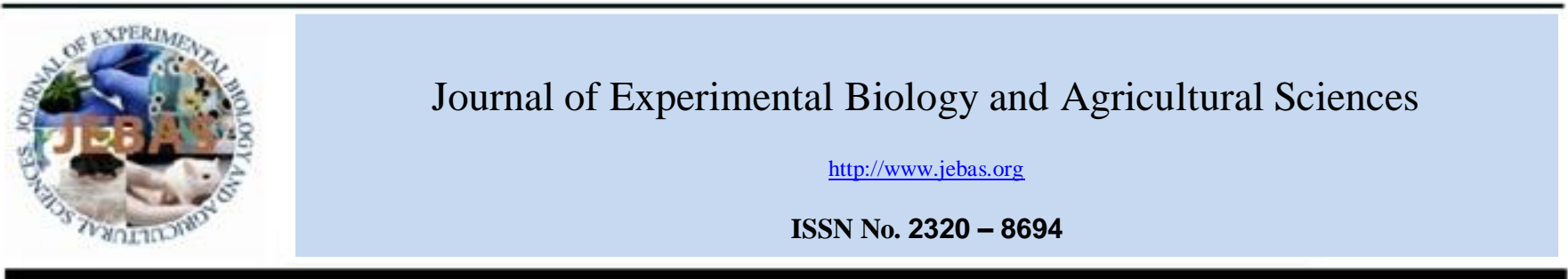

\title{
FORMS OF SULPHUR IN SOME BLACK SOILS OF VARANASI DISTRICT OF UTTAR PRADESH
}

\author{
Ashish Rai, Surendra Singh* \\ Department of Soil Science and Agricultural Chemistry, Institute of Agricultural Sciences, Banaras Hindu University, Varanasi, 221005, Uttar Pradesh-India \\ Received - October 19, 2018; Revision - November 30, 2018; Accepted - December 12, 2018 \\ Available Online - December 15, 2018
}

DOI: http://dx.doi.org/10.18006/2018.6(6).983.989

KEYWORDS
Sulphur
Fraction
Status
Black soil
Sulphur availability index
Correlation

\begin{abstract}
Information regarding sulphur (S) distribution in black soils of Varanasi district is meager. Therefore, present study was undertaken to assess the different forms of sulphur in black soils of Varanasi district, for this, 100 soil (0-15 cm depth) samples were collected by using global positioning system (GPS) from the Shahanshahpur village, Araziline block of Varanasi district, Uttar Pradesh. Analysis of soil samples revealed the presence of extractable sulphur $\left(\mathrm{SO}_{4}-\mathrm{S}\right)$ in soils which ranged (mean) from 7 to $33 \mathrm{mg} \mathrm{S} \mathrm{kg}$ ${ }^{1}\left(15 \mathrm{mg} \mathrm{S} \mathrm{kg}^{-1}\right)$ soil. The distribution pattern of sulphur was in the order of organic sulphur $(40 \%)>$ non sulphate sulphur $(30 \%)>$ adsorbed sulphur $(16 \%)>$ heat soluble sulphur $(11 \%)>0.15 \%$ extractable available sulphur (3\%). Perusal of the data shows positive and significant correlation between total sulphur, organic sulphur $(r=0.987)$, non sulphate sulphur $(r=0.601 * *)$ and heat soluble $S(r=0.803)$. Heat soluble $\mathrm{S}$ was also positively and significantly correlated with total $\mathrm{S}\left(\mathrm{r}=0.803^{* *}\right)$, organic sulphur $(\mathrm{r}=0.764 * *)$ and non sulphate sulphur $\left(\mathrm{r}=0.619^{* *}\right)$. The significant correlation amongst different forms of sulphur suggested an interrelated dynamic equilibrium in soils. Inferences drawn from the study on sulphur revealed that organic sulphur was determining factor in association with almost all the fractions of sulphur. Hence, organic matter thought to be good S-reservoir in these soils.
\end{abstract}

* Corresponding author

E-mail: ssinghssac@yahoo.co.in (Surendra Singh)

Peer review under responsibility of Journal of Experimental Biology and Agricultural Sciences.

Production and Hosting by Horizon Publisher India [HPI] (http://www.horizonpublisherindia.in/).

All rights reserved.
All the article published by Journal of Experimental Biology and Agricultural Sciences is licensed under a Creative Commons Attribution-NonCommercial 4.0 International License Based on a work at www.jebas.org.

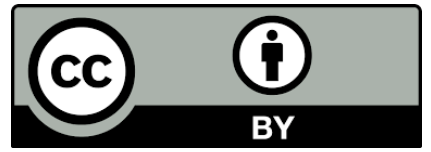




\section{Introduction}

Black soils of Varanasi district of eastern Uttar Pradesh are formed under water-logged conditions and developed in the gangetic alluvium and fall under Vertisols (Chromusterts). Black soils popularly known as black cotton soils, categorised under Vertisols soil order in soil classification system are usually deep to very deep and prevails smectitic type clays. Slickensides or wedge-shaped peds, $\geq 30 \%$ clay, swell-shrink nature and microgilgai are the main features and/or characteristics of these soils with linear extensibility (LE) of $6.0 \mathrm{~cm}$ or more. This higher linear extensibility caused by smectitic clays sub-divide these soils in to vertic sub-group (Soil Survey Staff 2006). According to recent reports Vertisols show its presence in Indogangetic Plains of India (Ray et al., 2006). These soils are predominantly found in Maharashtra, Madhya Pradesh, and Gujarat except some parts of Rajsathan, Kerala and Jammu \& Kashmir (Nair et al., 2006; Bhattacharyya et al., 2007; Mandal et al., 2012). These soils are poor in some available plant nutrients, especially nitrogen, phosphorus, sulphur and their calcareous nature adversely affects the availability of micronutrients. Varanasi district is located in the Indo-Gangetic plains and is the most productive region of the country. Imbalanced fertilization and mismanagement are the root causes of soil health deterioration in these black soils. Soils of the region are mostly used for vegetables and pulse growing purposes. Available nutrients in soils play pivotal role in determination of fertility status and sustainable productivity of the soils. Deficiencies of available major, secondary and micronutrients are widespread in soils of Varanasi district of eastern Uttar Pradesh (Tiwari et al., 2003).

Sulphur (S) is an essential nutrient for the plant growth and its metabolic activities. Its occurrence depends upon the parent materials and rocks from which soil is derived. Sulphur is a structural constituent of many co-enzymes and secondary plant products and acts as a functional group directly involved in metabolic reactions in plants. Further, it is an essential component for plant system which is present in soils in both organic and inorganic forms. Organic form particularly sulphate ester and carbon-bonded sulphur contributes approximately $75-90 \%$ of the total sulphur (Nguyen \& Goh, 1992; Schmidt et al., 2012; Arvind and Rai, 2018). Widespread sulphur deficiencies in soils and crops have increased worldwide because of low input of $\mathrm{S}$ in the soil (Singh, 2001; Singh, 2002; Singh, 2006). This might became the cause of valuable yield reduction in many crops. Sulphur deficiencies in soils are generally attributed due to low in organic matter, coarse-textured, well drained, and subject to leaching etc (Kost et al., 2008). Conversion of natural ecosystems into agricultural lands for intensive cultivation severely depletes soil organic carbon pools (Kumar et al., 2013) which ultimately depletes the sulphur content of the soil. Since organic matter and plant residues are major sources of plant-available sulphur in the soil. Sulphur deficiency, to a tune of 50 percent in soils of eastern districts of Uttar Pradesh is reported by Singh et al. (2015). Similarly, wide spread crop sulphur deficiency have been reported in Madhya Pradesh state of India (Chibber, 2007). Further, Singh \& Kumar (2012) and Singh et al. (2016) have been reported widespread sulphur and zinc deficiencies in the wheat growing alluvial soils of Araziline block of Varanasi district. Soil sulphur and its fractions can be an effective measure for the sulphur deficient areas for better management practices in future. No systematic effort yet has been made to diagnose the status and distribution of sulphur in black soils of the region. The present study was therefore, undertaken to study the above objective.

\section{Materials and Methods}

The Varanasi district lies between $25.14^{\circ}$ and $25.23^{\circ} \mathrm{N}$ latitude and $82.56^{\circ}$ and $83.03^{\circ} \mathrm{E}$ longitude, having an area of $1535 \mathrm{~km}^{2}$ comprised of eight Vikas khand (block) with a total of 1,327 villages. The majority of soils of Varanasi fall under alluvial (Inceptisols). Some part of Varanasi district has black soils in Araziline block locally known as Karail (Vertisols).

\subsection{Soil Sampling and Analysis}

Altogether GPS based 100 surface soil samples $(0-15 \mathrm{~cm})$ were collected randomly from Shahanshahpur village of Araziline block, Varanasi district (Figure 1). The soil samples were air-dried, processed with wooden pestle and mortar and sieved by 2-mm sieve and reduced to final volume of $500 \mathrm{~g}$ each and were kept in labeled sample bottles for analysis.

Sulphur fractionation analysis was done by selecting different methods; value of total-S was estimated by the acid digestion (Johnson \& Nishita, 1952); heat soluble sulphur (Williams \& Steinbergs, 1969); available sulphur $\left(0.15 \% \mathrm{CaCl}_{2}\right)$ (Williams \& Steinbergs, 1969) and adsorbed sulphur was calculated by deducting the values obtained with $0.15 \% \mathrm{CaCl}_{2}$ extractable $\mathrm{S}$ from those extracted with $500 \mathrm{ppm} \mathrm{Ca}\left(\mathrm{H}_{2} \mathrm{PO}_{4}\right)_{2}$ (Fox et al., 1964). Non sulphate sulphur was computed by subtracting the sum of organic $\mathrm{S}$ (Evans \& Rost, 1945) and available-S from the total S. Sulphur in all extracts was determined turbidimetrically (Chesnin \& Yien, 1950) using UVVisible spectrophotometer. Sulphur Availability Index (SAl) was calculated as per equation given by Donahue et al. (1977).

$\mathrm{SAI}=\left(0.4 \times \mathrm{CaCl}_{2}\right.$ extractable $\mathrm{SO}_{4}{ }^{2-}$ in $\mathrm{mg} \mathrm{kg}^{-1}$ soil $)+\%$ organic matter

Descriptive statistics of the available $\mathrm{S}$ and their fractions were obtained using data analysis in excel sheet. Simple correlation coefficients were derived to study the relationship among sulphur fractionation and SAI using SPSS 17.0 (SPSS Institute Inc., Chicago, IL, USA). 

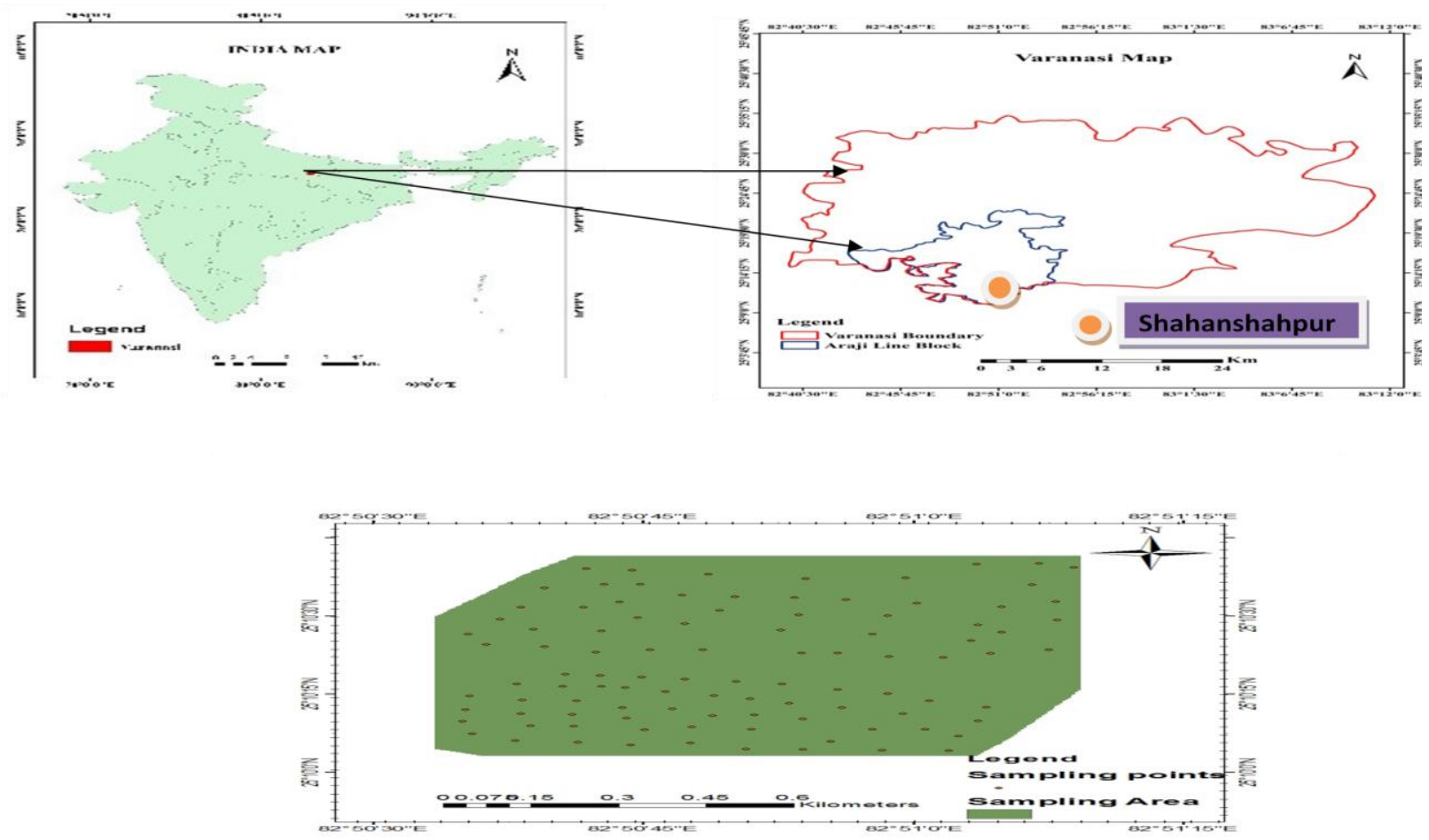

Figure 1 Sampling site of the study area, Shahanshahpur village in Araziline block of Varanasi district

\section{Results and Discussion}

\subsection{Available sulphur status}

Generally, available or plant available sulphur refers to the soluble and easily extractable sulphur utilized by the plants. It is a pool of sulphate $\mathrm{S}$ from mineral and oragnic sources which can be extracted by a suitable extractant $\left(0.15 \% \mathrm{CaCl}_{2}\right.$ solution or any other extractant like $500 \mathrm{ppm}$ solution of $\mathrm{KH}_{2} \mathrm{PO}_{4}$ ) and the amount extracted is significantly correlated with plant growth. The available $\mathrm{S}$ status in surface soils ranged from 7 to $33 \mathrm{mg} \mathrm{kg}^{-1}$ with a mean of $15.52 \mathrm{mg} \mathrm{S} \mathrm{kg}^{-1}$ soil (Table 1). Of the total samples 26, 48 and 26\% samples were found under low, medium and high categories, respectively. Most of the soil samples were tested as medium in available $\mathrm{S}$ (Table 1). Since, determination of available sulphur provides an estimate of the soils's sulphur fertility status which ultimately considered to be plant available.

\subsection{Different forms of sulphur}

\subsubsection{Total $S$}

Total soil sulphur is usually distributed among several fractions viz. organic S, non-sulphate sulphur and plant available sulphur (inorganic sulphur). As a matter of fact, total sulphur content is positively associated with the organic matter content which acts as a sulphur reservoir in the soil. The mean value of total sulphur and percent distribution of sulphur are presented in table 1 and figure 2, respectively. Mean value of total sulphur was found 352 $\mathrm{mg} \mathrm{S} \mathrm{kg}^{-1}$ soil (Table 1) and this lower value might be associated with lower amounts of organic carbon. It is established that soil organic carbon largely controls by regulating the binding capacity of $\mathrm{SO}_{4}$-S. As shown in table 2, total sulphur maintained a significant positive association with organic $\mathrm{S}$, heat soluble $\mathrm{S}$ and non-sulphate S. Such relationship suggests that sulphur exists in a state of dynamic equilibrium in these soils. Total $\mathrm{S}$ content indicates the reserve pool of this element in soils, may be attributed due to the presence of clay and some extent of organic carbon in these soils. Total S exhibited a significant positive correlation (Table 2) with organic sulphur $\left(\mathrm{r}=0.987^{* *}\right)$ and heat soluble sulphur $(r=0.803 * *)$. It is established that soil texture largely controls $\mathrm{S}$-status by regulating the leaching losses of soluble $\mathrm{SO}_{4}{ }^{2-}$ as reported earlier (Sarkar et al., 2007; Borkotoki \& Das, 2008; Kour \& Jalali, 2008; Paul \& Mukhopadhyay, 2009; Chattopaddhyay \& Ghosh, 2009; Basumatary et al., 2010). The close correlations suggest that the contents and the stocks of sulphur in the soils are controlled by the humification processes. Existence of similar relationship among various fractions of $\mathrm{S}$ was also reported by Basumatary et al. (2008). 
Table 1 Summary statistics for soil sulphur fractions and sulphur availability index of Black soils of Varanasi

\begin{tabular}{|lcccccc|}
\hline Sulphur forms & Minimum & Maximum & Mean & Kurtosis & Skewness \\
\hline Total sulphur & 151 & 608 & 352 & -1.294 & 0.178 \\
\hline Organic sulphur & 18 & 414 & 194 & -1.326 & 0.209 \\
\hline Non sulphate S & 96 & 211 & 142 & -0.244 & 0.605 \\
\hline Adsorbed S & 26 & 139 & 76 & 1.1278 & 1.035 \\
\hline $\mathrm{CaCl}_{2}$ extractable S & 7 & 33 & 15 & -0.383 & 0.667 \\
\hline Heat soluble sulphur & 26 & 77 & 53 & -0.739 & -0.196 \\
\hline Sulphur availability index & 3 & 14 & 7 & -0.312 & 0.667 \\
\hline
\end{tabular}

Table 2 Correlation amongst different $\mathrm{S}$ fractions

\begin{tabular}{|c|c|c|c|c|c|c|}
\hline & Total & Organic S & $\mathrm{SO}_{4}-\mathrm{S}$ & Heat-soluble S & Adsorbed S & Non sulphate $S$ \\
\hline Total S & 1 & & & & & \\
\hline Organic S & $0.987^{* *}$ & 1 & & & & \\
\hline $\mathrm{SO}_{4}-\mathrm{S}$ & 0.030 & 0.048 & 1 & & & \\
\hline Heat-soluble S & $0.803^{* *}$ & $0.764 * *$ & -0.009 & 1 & & \\
\hline Adsorbed S & 0.071 & -0.071 & $-0.346 * *$ & -0.011 & 1 & \\
\hline Non sulphate $S$ & $0.601^{* *}$ & $0.468 * *$ & $-0.280^{* *}$ & $0.619 * *$ & $0.767 * *$ & 1 \\
\hline
\end{tabular}

$*$ and $* *$ denote significant at $5 \%$ and $1 \%$ level, respectively

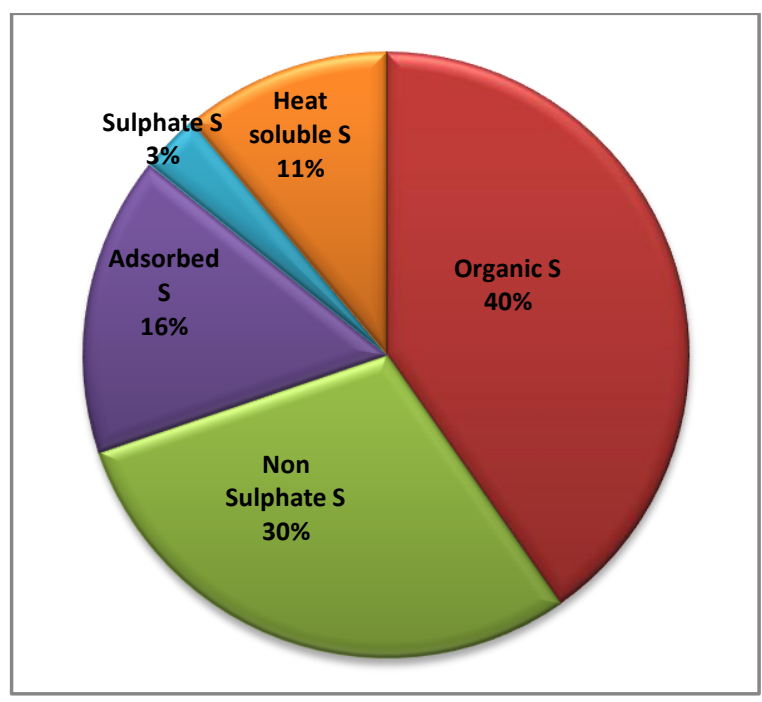

Figure 2 Distribution of sulphur in black soils of Varanasi

\subsubsection{Organic $S$}

Organic sulphur is a part of $\mathrm{S}$ containing organic compounds (proteins, cystein, cystine, methionine etc.) contributed mainly due to the leaflitter, animal wastes, crop residues, etc. Some researchers compute the value of organic sulphur indirectly by simply deducting available $\mathrm{S}$ from total $\mathrm{S}$ which inflates the figures of organic S (95\% in Inceptisols of West Bengal) as any non-sulphate sulphur also gets included in the organic $S$ fraction (Das et al 2006). The mean organic sulphur content of the soil was found $194 \mathrm{mg} \mathrm{S} \mathrm{kg}^{-1}$ soil. Organic S maintained a significant and positive relationship with all forms of $\mathrm{S}$ except $\mathrm{SO}_{4} \mathrm{~S}$ and adsorbed $\mathrm{S}$ (Table 2) suggesting a dynamic equilibrium among them (Tripathi \& Singh 1992; Chattopddhyay \& Ghosh 2009). Organic sulphur also correlated positively with heat soluble $\mathrm{S}$ ( $\mathrm{r}=$ $0.764 * *$ ). The organic $S$ was found to be the dominant fraction in soils and accounted for $40 \%$ followed by non sulphate S (30\%), adsorbed S (16\%) and heat soluble S (11\%) of total S in these soil samples. Possible explanations for the distribution of the organic sulphur fraction might be difference in microbial ecology from upper to lower depths in the soil, the sulphate ester constitutes the major fraction in surface soils (Stickland et al., 1987; Dhamala et al., 1990); generation of sulphate esters would be consisted with the sulphate flux variation in surface soil (Mac Laren et al., 1985). Decomposition and humification of organic sulphur compounds inherited from plants residues is directly linked with the soils and consequently mineralized and generates sulphates used for plant and microbial uptake (Stevenson, 1982). However, organic sulphur is a more dominant fraction of total $\mathrm{S}$ in temperate regions than in warmer climates. 


\subsubsection{Non sulphate $S$}

This fraction consists primarily of occluded/precipitated $\mathrm{S}$ and which can vary from less than 5 to over $50 \%$ of total S. Its distribution pattern is generally reverse of organic $\mathrm{S}$. Non sulphate $\mathrm{S}$ was computed by subtracting the sum of organic $\mathrm{S}$ and sulphate $\mathrm{S}$ from the total S. It is mostly made up of $\mathrm{SO}_{4}{ }^{2-}$ occluded on carbonates (Evans \& Rost 1945) or insoluble S compounds of $\mathrm{Fe}$ and $\mathrm{Al}$ in soil which remain unextractable even after removal of organic carbon and $\mathrm{SO}_{4}-\mathrm{S}$ (Balanagoudar \& Satyanaranyana, 1990). The results revealed that non-sulphate $\mathrm{S}$ content varied from 96 to $211 \mathrm{mg} \mathrm{kg}^{-1}$ with a mean of 142 $\mathrm{mg} \mathrm{S} \mathrm{kg}^{-1}$ soil (Table 1) and it constituted about $30 \%$ of total S. In Assam soils, this fraction formed $11-17 \%$ of total S (Borkotoki \& Das 2008). In three agroclimatic regions of Jammu region, non-sulphate $\mathrm{S}$ formed $30 \%$ of total $\mathrm{S}$ in the temperate zone, $45 \%$ in interediate zone and $53 \%$ in the subtropical zone (Kour \& Jalali 2008).

\subsubsection{Adsorbed $S$}

The 500 ppm Ca $\left(\mathrm{H}_{2} \mathrm{PO}_{4}\right)_{2}$ solutions extracts the $\mathrm{SO}_{4}{ }^{2-}$ ions from the exchange complex of soil and contains both exchange complex adsorbed $\mathrm{SO}_{4}{ }^{2-}$ and $\mathrm{S}$ in soil solution. Thus the adsorbed $\mathrm{S}$ can be obtained by deducting the values of available $\mathrm{S}\left(0.15 \% \mathrm{CaCl}_{2}\right.$ extractable $\left.\mathrm{SO}_{4}-\mathrm{S}\right)$ from that of $\mathrm{Ca}\left(\mathrm{H}_{2} \mathrm{PO}_{4}\right)_{2}$ extractable $\mathrm{S}$. It was accounted for the $16 \%$ of the total $\mathrm{S}$ and ranged from 26 to $139 \mathrm{mg} \mathrm{kg}^{-1}$ with a mean of 76 $\mathrm{mg} \mathrm{S} \mathrm{kg}{ }^{-1}$ soil (Table 1), this may be attributed due to nondisplacement of adsorbed $\mathrm{SO}_{4}{ }^{2-}$ under medium rainfall in Varanasi which restricts the leaching loss of $\mathrm{SO}_{4}{ }^{2-}$ ions in lower layers. The adsorbed $\mathrm{SO}_{4}{ }^{2-}$ had a highly significant positive correlation with non-sulphate $\mathrm{S}(0.767 * *)$ (Table 2$)$. When compared with $\mathrm{CaCl}_{2}$, the higher observed extractability of $\mathrm{Ca}\left(\mathrm{H}_{2} \mathrm{PO}_{4}\right)_{2}$ is most likely due to the phosphate solution being able also to extract a portion of the labile soil organic $\mathrm{S}$ (Zhao \& Macgrath 1994). Similar relationship among various fractions of S was also reported by Basumatary et al. (2008). However, contribution of subsoils to plant S uptake cannot be ignored in good grainage conditions (Hue \& Cope, 1987). For this reason, an extractant containing phosphate which can adsorb sulphate is preferred.

\subsubsection{Sulphate $S$}

This form of $\mathrm{S}\left(0.15 \% \mathrm{CaCl}_{2}\right.$ extractable $\left.\mathrm{SO}_{4}-\mathrm{S}\right)$ is used as an index of $\mathrm{S}$ availability in many soils for plant growth and subsequently reductions in yield and $\mathrm{S}$ uptake in crops in many soils caused by variation in this form. This form of $\mathrm{S}$ contributed about $3 \%$ total $\mathrm{S}$ and ranged from 7 to $33 \mathrm{mg} \mathrm{kg}^{-1}$ with mean of $15 \mathrm{mg} \mathrm{S} \mathrm{kg}^{-1}$ soil (Table 1). However, this form of sulphur was negatively correlated with non sulphate $S$ and adsorbed $\mathrm{S}$ and result was opposite to general expectations. $\mathrm{CaCl}_{2}$ extraction appears to be a less soil dependent measurement (Ketterings et al., 2011), also reflecting well the changes in soil available $\mathrm{S}$ in soils having a high $\mathrm{pH}$. Analyses of $\mathrm{S}$ in $\mathrm{CaCl}_{2}$ soil extracts, in general provide a measure of soil inorganic $\mathrm{S}$, because $\mathrm{CaCl}_{2}$ extracts mostly $\mathrm{SO}_{4}-\mathrm{S}$ (Zhao \& Macgrath, 1994). However, extractable organic $\mathrm{S}$ is regarded as plant available $\mathrm{S}$ as it is readily mineralized to $\mathrm{SO}_{4}-\mathrm{S}$ (Anderson et al., 1992). In general, $\mathrm{S}$ in $\mathrm{CaCl}_{2}$ soil extracts provides a measure of soil inorganic $\mathrm{S}$, because $\mathrm{CaCl}_{2}$ extracts mostly $\mathrm{SO}_{4}-\mathrm{S}$ (Goh \& Tsuji, 1979). However, results revealed that available $S$ was fall under medium category. Moreover, two compartments of the ecosystems are involved in the sulphur retention viz. sulphur assimilation by the plant uptake and incorporated in the vegetation biomass and the soil cover.

\subsubsection{Heat soluble sulphur}

This form of $\mathrm{S}$ constituted about $11 \%$ of the total $\mathrm{S}$ and is an indicator of the mineralizable $\mathrm{S}$ present in the soil. The heat soluble sulphur content was comparatively larger than available $S$ or sulphate S. It exhibited a range from 26 to $77 \mathrm{mg} \mathrm{kg}^{-1}$ with a mean of $53 \mathrm{mg} \mathrm{S} \mathrm{kg}^{-1}$ soil (Table 1). Heat soluble $\mathrm{S}$ was positively and significantly correlated with total $\mathrm{S}$, organic $\mathrm{S}$ and nonsulphate $S$ which indicates that almost all forms of $S$ had contributed towards heat soluble S. It is a matter of fact that heating of soil may liberate greater amount of S covalently bonded to organic matter (Aderichin, 1960).

In general, organic sulphur had positive association with almost all the fractions of sulphur (except adsorbed and available $\mathrm{S}$ ) and hence, organic matter could be thought of as a good S-reservoir in the soils (Borkotoki \& Das 2008). Conversely, available S and adsorbed sulphur had negative or very low positive correlations with all forms of sulphur. This might be due to the presence of $\mathrm{H}^{+}$ and $\mathrm{OH}^{-}$ions on soil complex, where $\mathrm{SO}_{4}{ }^{2-}$ ions are attracted to $\mathrm{H}^{+}$ions with the formation of insoluble compounds of $\mathrm{S}$.

\section{Conclusion:}

It is concluded from the present investigation that the intensively crop growing cultivated black soils of Varanasi showed medium sulphur status. The relationship studies between different forms of sulphur revealed that, in general, organic sulphur had positive association with almost all the fractions of sulphur (except adsorbed and available S) and hence, organic matter could be thought of as a good S-reservoir in the soils.

\section{Acknowledgement}

Authors are highly grateful to Department of Soil Science and Agricultural Chemistry, Institute of Agricultural Sciences, 
Banaras Hindu University, Varanasi-221005 for providing necessary assistance and facilities during research work.

\section{Conflict of Interest}

The authors declare that there is no conflict of interest regarding the publication of this research paper.

\section{References}

Aderichin PG (1960) Transcript of first International congress of soil science, Madison, US 2, Pp. 281.

Anderson GC, Lefroy RDB, Chinoim N, Blair GJ (1992) Soil sulphur testing. Sulphur Agriculture 16: 6-14.

Arvind, Rai A (2018) Effect of sulphur and boron levels on soil available nutrients after harvesting of sesame (Sesamum indicum L.) in red soil of Mirzapur. International Journal of Plant \& Soil Science 25: 1-7.

Balanagoudar SR, Satyanarayana T (1990) Depth distribution of different forms of sulphur in Vertisols and Alfisols. Journal of the Indian Society of Soil Science 38: 640-645.

Basumatary A, Das KN, Borkotoki B (2010) Interrelationship of sulphur with soil properties and its Availability Index in some rapeseed growing Inceptisols of Assam. Journal of the Indian Society of Soil Science 58: 394-402.

Basumatary A, Talukdar MC, Ramchiary S (2008) Sulphur forms and their relationship with soil properties in rapeseed growi.ng soils of Upper Assam. International Journal of Tropical Agriculture 26: 69-72.

Bhattacharyya T, Pal DK, Chandran P, Ray SK, Durge SL, Mandal C, Telpande B, (2007) Available K reserve of two major crop growing regions (alluvial and shrink-swell soils) in India. Indian Journal of Fertilizers 3: 41-52.

Borkotoki B, Das KN (2008) Forms of sulphur and their relationship with soil properties in Entisols, Inceptisols and Alfisols of Assam. Journal of the Indian Society of Soil Science 56: 186-191.

Chattopaddhyay S, Ghosh GK (2009) Vertical distribution of forms of sulphur in some profiles of Birbhum district of West Bengal. Journal of Interacademicia 13: 28-35.

Chesnin L, Yien CH (1950) Turbidimetric determination of available sulphates. Soil Science Society of America14: 149-151.

Chibber N (2007) Sulphur deficiency in Madhya Pradesh soil leads to poor harvest. Down to Earth. Available at http://www.downtoearth.org.in/full6.asp?foldername=20070815\& filename $=$ news\&sec_id $=4 \&$ sid=3 (verified 23 Mar. 2008).

Das 1, Ghosh K, Ray SC, Mukhopadhyay PK, Ghosh SK (2006) Status and distribution of sulphur vis-a-vis taxonomic class wise distribution of sulphur in selected soils series of Inceptisol in West Bengal. Journal of the Indian Society of Soil Science 54: 368-371.

Dhamala BR, Mitchell MJ, Stam AC (1990) Sulfur dynamics in mineral horizons of two northern hardwood soils. A column study with ${ }^{35}$ S. Biogeochemistry 10: 143-160.

Donahue RL, Miller RW, Shickluma JC (1977) An Introduction to Soil and Plant Growth. 4th edition, Prentice Hall Inc. New jersy, USA, Pp 209.

Evans CA, Rost CO (1945) Total organic sulphur and humus sulphur of Minnesota soils. Soil Science 59: 125-137.

Fox RL, Olsen RA, Rhoades HF (1964) Evaluating the sulfur status of soils by plant and soil tests. Soil Science Society of America Proceeding 28: 243-246.

Goh KM, Tsuji T (1979) Changes in soil sulphur fractions during incubation with and without added sulphur. New Zealand Journal of Agricultural Research 22: 585-594.

Hue NV, Cope JT Jr. (1987) Use of soil-profile data for predicting crop response to sulfur. Soil Science Society of America Journal 51: 658-664.

Johnson CM, Nishita H (1952) Micro-estimation of sulfur in plant materials soils and irrigation waters. Analytical Chemistry 24: 736-742.

Ketterings Q, Miyaoto C, Mathur RR, Dietzel K, Gami S (2011) A comparison of soil sulphur extraction methods. Soil Science Society of America Journal 75: 1578-1583.

Kost D, Cheng L, Dick WA (2008): Predicting plant sulfur deficiency in soils: results from Ohio. Biology and Fertility of Soils 44: 1091-1098.

Kour S, Jalali VK (2008) Forms of sulphur and their relationship in soils of different Agroclimatic zones of Jammu region. Journal of the Indian Society of Soil Science 56: 309-312.

Kumar R, Rawat KS, Singh J, Singh A, Rai A (2013) Soil aggregation dynamics and carbon sequestration. Journal of Applied and Natural Science 5: 250-267.

MacLaren RG, Keer JI, Swift RS (1985) Sulphur transformations in soils using sulphur-35 labelling. Soil Biology and Biochemistry 17: 73-79. 
Mandal C, Mandal DK, Jagdish Prasad, Dipak Sarkar, Chandran P, Tiwary P, Patil NG, Obi Reddy GP, Lokhande MA, Wadhai KN, Dongare VT, Sidhu GS, Sahoo AK, Nair KM, Singh RS, Pal DK, Ray SK, Bhattacharyya T (2012) Revision of Black Soil Map of India for Sustainable Crop Production. Available on https://www.researchgate.net/publication/322420294_Revision_of _Black_Soil_Map_of_India_for_Sustainable_Crop_Production accessed on October 042018.

Nair KM, Dhanorkar BA, Ramesh Kumar SC, Sujatha K, Suresh Kumar, Premachandran PN, Vadivelu S (2006) Soil of Kozhinjampara Panchayat, NBSS Publ. No. 960, National Bureau of Soil Survey and Land Use Planning, Nagpur.

Nguyen M L, Goh K M (1992) Status and distribution of soil sulphur fractions, total nitrogen and organic carbon in camp and non-camp soils of grazed pastures supplied with long-term superphosphate. Biology and Fertility of Soils 14: 181-190.

Paul SC, Mukhopadhyay P (2009) Forms and status of sulphur in some soils of terai region of West Bengal. Environment and Ecology 27: 1521-1523.

Ray SK, Bhattacharyya T, Chandran P, Sahoo AK, Sarkar D, Durge SL, Raja P, Maurya UK, Pal DK (2006) On the formation of cracking clay soils in West Bengal. Clay Research 25, 141-152.

Sarkar M, Ghosh SK, Mukhopadhyay P, Pal SK (2007) Distribution of sulphur and its relationship with soil properties in some soil series (Alfisols) of West Bengal. Agropedology 17:113-117.

Schmidt F, Fabiano Daniel De B, Cristiane Prezotto S, Francisco Antonio M (2012) Soil sulfur fractions dynamics and distribution in a tropical grass pasture amended with nitrogen and sulfur fertilizers. Journal of Plant Nutrition and Soil Science 175: 60-67.

Singh MV (2001) Importance of sulphur in balanced fertilizer use in India. Fertilizer News $46: 13-35$.

Singh MV (2002) Micro and secondary nutrient management for doubling productivity of oilseed-based cropping systems. In: Gangwar et al.(Eds.), Proceedings of oilseed based cropping system - issues and technologies, PDCSR, Modipuram 1: 51-67.

Singh MV (2006) Micro and secondary nutrients and pollutant elements research in India. Progress report, IISS, Bhopal, pp. 1-110.
Singh S, Kumar P (2012) Soil fertility status of vegetables growing area of Varanasi and pulses growing area of Mirzapur. Journal of the Indian Society of Soil Science 60: 233-236.

Singh SK, Dey P, Singh S, Sharma PK, Singh YV, Latare AM, Singh CM, Kumar D, Kumar O, Yadav SN, Verma SS (2015) Emergence of boron and sulphur deficiency in soils of Chandauli, Mirzapur, Sant Ravidas Nagar and Varanasi districts of Eastern Uttar Pradesh. Journal of the Indian Society of Soil Science 63: 200-208.

Singh YV, Singh SK, Sahi SK, Verma SK, Yadav RN, Singh PK (2016) Evaluation of soil fertility status from Milkipur village, Araziline Block, Varanasi district Uttar Pradesh in relation to soil characteristics. Journal of Pure and Applied Microbiology 10: 1455-1461.

Soil Survey Staff (2006) Keys to Soil Taxonomy, United States Department of Agriculture, Natural Resources Conservation Service, Washington, DC, 2006, 10th edn.

Stevenson FJ (1982) Humus chemistry: genesis, composition, reactions. Wiley-Interscience, Wiley, New York 443.

Stickland TC, Fitzgerald JW, Ash JT, Swank WT (1987) Organic sulfur transformations and sulfur pool sizes in soil and litter from a southern Appalachian hardwood forest. Soil Science 143:453-458.

Tiwari RC, Agarwal HP, Maurya BR, Narayan D (2003) Organic matter recycling and enrichment. Department of Soil Science and Agricultural Chemistry, Institute of Agricultural Sciences, Banaras Hindu University Varanasi. Final Report of the Research Project, Submitted to ICAR (NATP), New Delhi pp 36-41.

Tripathi D, Singh K (1992) Vertical distribution of sulphur in representative soil groups of Himachal Pradesh. Journal of the Indian Society of Soil Science 40: 447-453.

Williams CH, Steinberg A (1969) Soil sulphur fractions as chemical indices of available sulphur in some Australian soils. Australian Journal of Agricultural Research 10: 340-352.

Zhao F, McGrath SP (1994) Extractable sulphate and organic sulphur in soils and their availability to plants. Plant Soil 164: 243-250. 